\title{
Euphemism Found in Mangongkal Holi Tradition
}

\author{
Charles David Marudut Silalahi ${ }^{1}$, Robert Sibarani ${ }^{2}$, Eddy Setia $^{3}$, Mohammad Takari ${ }^{4}$ \\ $\left\{\right.$ lie.chuck.dave@gmail.com ${ }^{1}$,rs_sibarani@yahoo.com $\left.{ }^{2}\right\}$ \\ ${ }^{1234}$ Universitas Sumatera Utara, Indonesia
}

\begin{abstract}
This paper investigates euphemism strategies used in Batak Toba's Mangongkal Holi tradition. Since Mangongkal Holi is the highest level of tradition in Batak Toba society, it is very important to acknowledge the community and others through the cultivication of oral tradition values found in it. The data analysis procedures follow the Miles, Huberman, and Saldana's Interactive model (2014)[1]; where those data display, data condensation, as well as the data verification are those three-concurrent flows that should be done in a sequence of time. It shows that there are 'figurative', 'part-for-whole', 'overstatement', 'understatement', 'metaphor', 'general-for-specific', and 'jargons' which can be attributed to cultural and religious beliefs and values. The study also reveals that there is no relationship between euphemism strategy choice and gender. Another significant finding is that Euphemistic language, like language in general, is influenced by its users' cultural and religious beliefs, life-styles, and norms.
\end{abstract}

\footnotetext{
Keywords - Euphemism strategies, Pragmatics, Oral Tradition, Mangongkal Holi
}

\section{Introduction}

Etymologically, 'euphemism' originated from Greek, 'euphemismos' with the prefix 'eu', meaning 'good' or 'well' and the root 'phemi' which means 'speaking'. Therefore, euphemism means 'speaking well'[2]. In a historical review, [3] Euphemism, as a linguistic phenomenon, flourished in religious subjects.

One of the cultural reflections in language is the speakers and/or writers' attempt to coverup certain words or expressions prohibited in public by individuals, communities or religions. This process is what is linguistically called euphemism [4]. [5] The unpleasantness of certain subjects, such as death, lying, or criminality, is neutralized by euphemistic expressions. Thus, euphemism is mainly used to avoid a 'taboo' and express 'politeness'. Furthermore [6] sometimes euphemism should not apply in a certain context, since it would avoid the speaker to express their mind in 'frankly speaking'.

Based on the above quotation, the writer define euphemism as 'a mild or round about word or expression used to make one's language delicate and inoffensive even to a squeamish person' or 'the extension of ordinary words and phrases to express unpleasant or embarrassing ideas, and to soften or conceal something unpleasant'. 
In general, batak toba's never allow the real host speaks to the audience personally, especially in the context of traditional event. They have to choose a certain spokesperson called as 'raja parhata', 'parsinabung'; he will represent the host in delivering their proposals to the audience. Actually it is avoided the host personal subjectivity and to keep them away from the impolite and rugged expressions to their respected family.

Euphemism as a universal phenomenon exists in all cultures. [7] Evidence indicates that euphemisms are a universal feature of language usage. Despite similarities, there are many differences, which can be attributed to different beliefs, customs, life-styles, and behaviors.

In Mangongkal Holi tradition, as acknowledged as the highest level tradition in Batak Toba society [8], the expressions expressed by those spokesperson can be categorized as polite dictions. Since they deliver their messages in figurative language, which consisted euphemistic meaning, called as umpasa and umpama.

Mangongkal Holi tradition has three congruent participants, they are: host's spokesperson (dongan tubu), wife's deliver's spokespersons (hula-hula), wife's receiver's spokesperson (boru/bere/ibebere). Simply, the host's spokesperson should speak humbly and politely to their hula-hula; to show their good manner so that the hula-hula would agree to the host's proposal/beg. In other hand, host's boru's spokesperson should speak more humbly/politely to their hula-hula, as well as their hula-hula's hula-hula. Those communicative links indicate the concept of 'dalihan na tolu' (three legs fireplace), where even hula-hula usually positioned in the first rank, followed by the dongan tubu and boru, but their existences on the traditional events will be equally needed.

\section{Methods}

In collecting the data of the research, the researchers do a field research through a direct participant observatory; where the researcher attended the traditional events both on Mangongkal Holi traditions in Sidamanik regency (Simalungun District) and Ronggur ni Huta regency (Samosir District). The data analysis procedures follow the Miles, Huberman, and Saldana's Interactive model; where those data display, data condensation, as well as the data verification are those three-concurrent flows that should be done in a sequence of time. The flows could be seen as follows:

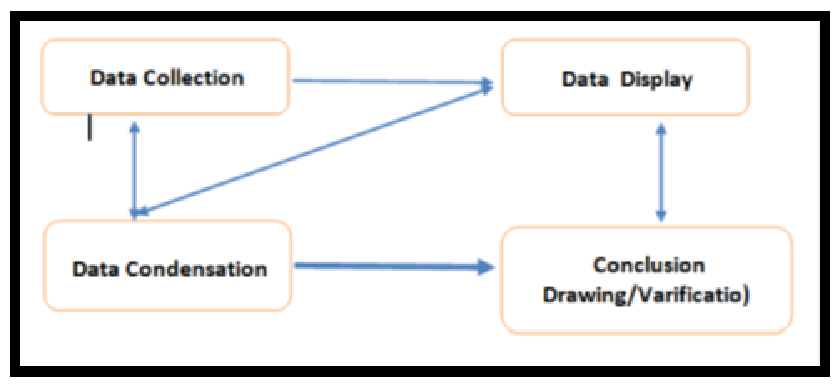

Fig. 1. Miles, Hubberman and Saldana's Interactive Model

Mangongkal Holi tradition consist of seven (7) phases of session, they are: Tonggo Raja (Royal's Meeting), Paumbanghon Saring-Saring (Excevating the Bones), Panangkokhon Saring-Saring tu Batu na Pir (Uplifting the Bones to the higher places called Tambak na Timbo), Sulang Bao (Feeding the Wife's Deliverer), Mangaliat Horbo (Sacrificing the Water 
Bufallo), Mambuat tua ni Gondang (Starting the Gondang Officially), and Pesta Adat na Gok (The Great Party). This tradition would be done in 2-7 days, it depends on how many persons/cemeteries would be excavated and how many water buffalo that would be sacrificed. In order to simplify and shorten the process of data analysis, the writer limited the data only based on the Royal's Meeting. Since Royal Meeting is classified as a phase in which all the further steps/sessions will be discussed and decided by the floor. And all of the activities that would be done later, must be based on the decisions made by those participants in the meeting (hosts, wife's deliverer, wife's receiver, and the neighbour/community surround).

\section{Result and Discussion}

The appearance of Euphemistic expressions in Mangongkal Holi Tradition. Here are the euphemistic data found in the activity of Mangongkal Holi tradition in Batak Toba society:

Table 1. Euphemistic Expressions found in Mangongkal Holi Tradition

\begin{tabular}{|c|c|c|c|}
\hline No & Original text & Meaning & $\begin{array}{c}\text { Types of } \\
\text { Euphemism }\end{array}$ \\
\hline 1 & $\begin{array}{l}\text { Natua-tua ni Huta: } \\
\text { Nunga be sae hita mangan jadi 'dia } \\
\text { lakkatna, dia hatana' }\end{array}$ & $\begin{array}{l}\text { Community Chief: } \\
\text { We've dined, so what do you } \\
\text { want to say, actually? }\end{array}$ & metaphor \\
\hline 2 & $\begin{array}{l}\text { JBPHB: } \\
\text { molo dung sikkop do sude pangkataion } i \\
\text { naung hata ni marga Sidabukke ma } i \\
\text { ate, alai molo adong nasalah salahku } \\
\text { sandiri ma i ai so holan au na salah. }\end{array}$ & $\begin{array}{l}\text { Host's Spokesperson: } \\
\text { If the meeting has } \\
\text { accomplished, declare it as } \\
\text { Sidabukke's clan statements, } \\
\text { but there is something wrong, it } \\
\text { would be mine. }\end{array}$ & understatement \\
\hline 3 & $\begin{array}{l}\text { Natua-tua ni Huta: } \\
\text { Mauba ma tu daging, marsaudarama tu } \\
\text { bohi sipalopit imbulu ma i sipanaikhon } \\
\text { holi-holi; }\end{array}$ & $\begin{array}{l}\text { Community Chief: } \\
\text { May the food we ate uplift the } \\
\text { number/mass of our blood, } \\
\text { flesh, hairs, bones. }\end{array}$ & overstatement \\
\hline 4 & $\begin{array}{l}\text { Natua-tua ni Huta: } \\
\text { Tuak namarhalto mai natubu dirobean, } \\
\text { Horas dihami angka Raja } \\
\text { namanganhon, } \\
\text { Tubu angka sikkap dihamuna } \\
\text { mangalean. }\end{array}$ & $\begin{array}{l}\text { Community Chief: } \\
\text { We are very happy to eat your } \\
\text { food, and hoping that you } \\
\text { would be pleased to offer us } \\
\text { more in the future. }\end{array}$ & figurative \\
\hline 5 & $\begin{array}{l}\text { JBPHB: } \\
\text { Rajanami dinamanungkun majo tutu tu } \\
\text { Rajai aha do lao sihataan nami } \\
\text { Rajanami panggabean panghorason do } \\
\text { Rajanami, sidot-doti ma hami. }\end{array}$ & $\begin{array}{l}\text { Host's Spokesperson: } \\
\text { Our Majesty, when you ask to } \\
\text { the topic that we would discuss; } \\
\text { it's only good news our Lord. }\end{array}$ & part-for-whole \\
\hline 6 & $\begin{array}{l}\text { Natua-tua ni Huta: } \\
\text { Asa tangkas purba, tangkas angkola; } \\
\text { Tangkas hami manungkun, tangkas ma } \\
\text { hamu marboa-boa } \\
\text { Dia ma sihombar na dia siudur na. }\end{array}$ & $\begin{array}{l}\text { Community Chief: } \\
\text { To make it clear, we will ask } \\
\text { you frankly, and hope you will } \\
\text { do the same thing; what would } \\
\text { like to say to the } \\
\text { floor/audience? }\end{array}$ & figurative \\
\hline 7 & $\begin{array}{l}\text { JBPHB: } \\
\text { Tanda ma tutu Raja i parbahul toba, }\end{array}$ & $\begin{array}{l}\text { Host's Spokesperson: } \\
\text { It's the proof that you are truly }\end{array}$ & $\begin{array}{l}\text { general } \\
\text { specific }\end{array}$ \\
\hline
\end{tabular}




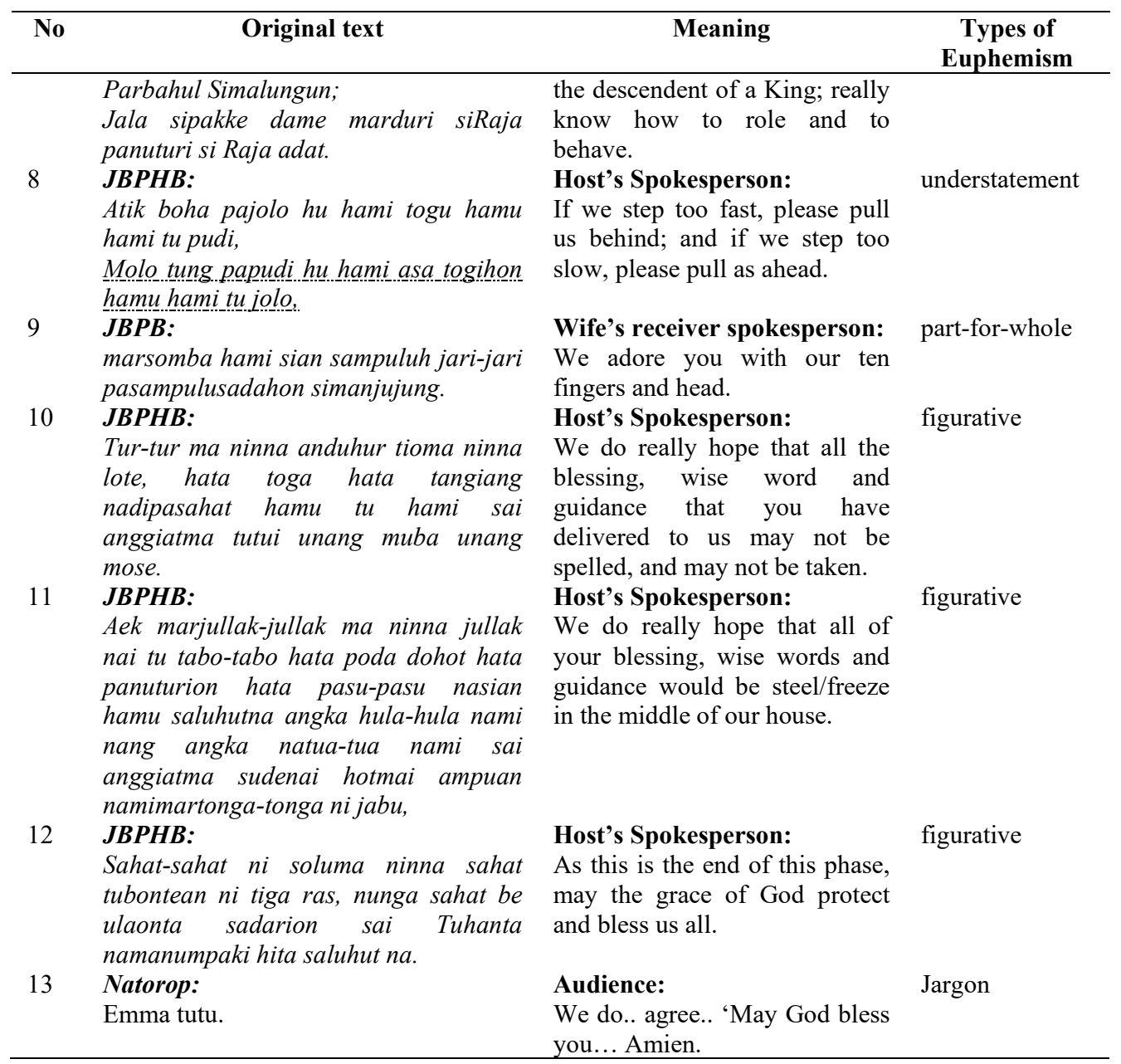

Actually, umpasa and umpama equal to proverbs or poetry, they consist of figurative meaning, since they inserted the meaning indirectly to the hearer or audiences. Somehow, the figurative sentence would give any manifestation of meaning, such as: metaphor, overstatement, understatement, par-for-whole, general to specific, and jargon.

In datum 1, the word 'lakkat' (skin/wrap) is compared with 'hata' (words), that's why it is classified as metaphorical euphemism; while in datum 13 Emma tutu could be meant as Amen, Agree, Deal, We do, May God bless you, and it is classified as jargon euphemism.

In data 5 and 9, there are part of the object/terms used to describe the whole elements of meaning, such as: 'panggabean, parhorasan' as small part of the whole topic that the host's spokesperson would like to define; on the other hand, the word 'sappulu jari-jari' and 'pasampulusada simanjunjung' represent the whole body who adore/respect the hulahula/tulang.

In data 2 and 8 , the spokesperson try to humiliate himself in front of the audiences, he pretends that he was an inexperienced, unprofessional one. In fact he was experience, capable and skillful to do the responsibility. 
In datum 3, the community chief try to overstatement his expression through states, may the food they ate uplift the number/mass of their blood, flesh, hairs, bones in once occasion; what an exaggerated expression.

In data 10,11, and 12 the figurative expressions are responding to the audiences' blessings, wise words, guidance that have been delivered to the host's family. It consists of thankfulness, pray, and hope to the God as well as to the wife's deliverer, so that they would please to bless and guide them ever after.

Does Gender Effect Euphemism strategy use in Mangongkal Holi Tradition?

Mostly, males are functioned as the participants as well as the spokesperson in any batak toba's tradition events. However, the appearance of female is possibly happened since she represents her husband/family if her husband has died or has been in a different place (apart from the place/location).

In a common situation, while the group of hula-hula/tulang (wife's deliverer) wants to express their blessing as well as wise words, guidance to the host's family, the head of the group will give a chance to their wives (paniaran) to express their words, but commonly the format and the way they express will not be different.

\section{Conclusion}

The most frequently euphemistic type used in Mangongkal Holi tradition are figurative, followed by part-for-whole, overstatement, understatement, metaphor, and jargon. Those euphemistic expressions can be attributed to cultural and religious beliefs and values. The spokesperson use euphemism on their words since they are speaking in a formal situation, consist of many respected persons, as well as their 'wife's deliverer' (hula-hula/tulang). The understatement, part-for-whole, usually come from the host's spokesperson, and from the wife's receiver family while overstatement, usually expressed by the wife's deliverer families (hula-hula/tulang).

\section{References}

[1] Miles et al, Qualitative Data Analysis: A Methods Sourcebook, 3rd Editio. Arizona: SAGE, 2014.

[2] T. McArthur, The Oxford Companion of the English Language. New York: Oxford University, 1992.

[3] J. Neaman and C. Silver, Kind Words: A Thesaurus of Euphemisms. New York: Facts on File, 1983.

[4] K. Allan and K. Burridge, Euphemism and Dysphemism: Language Used as a Shield and Weapon. New York: Oxford University, 1991.

[5] R. Wardhaugh, An Introduction to Sociolinguistics. Malden, MA: Blackwell, 2006.

[6] E. Kuntjara, Eufemisme dan Bahasa Perempuan. Universitas Kristen Petra, 2009.

[7] P. Brown and S. C. Levinson, Politeness: Some Universals in Language Usage. Cambridge: Cambridge University, 1987.

[8] C. Silalahi and E. Al, "Mangongkal Holi as the Highest Level of Tradition in Batak Toba Society," Journal Methoda, pp. 1-9, 2016. 